\title{
AUDIT REPORT LAG OF LISTED COMPANIES IN INDONESIA STOCK EXCHANGE
}

\author{
Nur Mazkiyani $^{1^{*}}$, Sigit Handoyo ${ }^{2}$ \\ 1,2 Jurusan Akuntansi, Universitas Islam Indonesia
}

\begin{abstract}
Recently, the timeliness of audited financial statement contributed enormously in the consideration of decision-making process. Therefore, the audited financial statement must be published on time, as well as the availability and accuracy of the financial information required for shareholders, investors and other users as decision makers. Interval time to the completion of financial statement audit report can be measured by duration of the days required to obtain independent auditor report. The duration counted from the date of companies' financial statement year-end until the date of audit report, known as audit report lag. Previous research regarding audit report lag has been conducted, along with the results that show some of factors which are significantly affect audit report lag including; company size, profitability, public accounting firm, auditors' opinion, leverage, solvability, type of industry and profit / loss operation. This research aims to analyze factors that affect audit report lag in some of public companies in Indonesia. This research examines the influence of company size, profitability, solvability, age of company, accounting firm size and audit committee towards audit report lag. The total sample consists of 332 firm-years observations of manufacturing companies listed in Indonesia Stock Exchange during 2009-2012. Analysis hypothesis is using multiple regressions. The results of multiple regression show that profitability and accounting firm size significantly influence audit report lag. Whereas, company size, solvability, age of company and audit committee does not influence audit report lag.
\end{abstract}

Keywords: Audit report lag, company size, profitability, solvability, age of company, accounting firm size, audit committee.

\begin{abstract}
ABSTRAK
Akhir-akhir ini, ketepatan waktu laporan keuangan yang telah diaudit memberikan kontribusi besar dalam pertimbangan proses pengambilan keputusan. Oleh karena itu, laporan keuangan yang telah diaudit harus dipublikasikan secara tepat waktu, karena ketersediaan dan juga keakuratan informasi keuangan diperlukan bagi pemegang saham, investor dan pengguna lain sebagai pengambil keputusan. Jangka waktu penyelesaian audit laporan keuangan dapat diukur berdasarkan lamanya hari yang dibutuhkan untuk memperoleh laporan auditor independen, terhitung sejak tanggal tahun tutup buku perusahaan sampai tanggal yang tertera pada laporan auditor independen, dikenal dengan audit report lag. Penelitian sebelumnya mengenai audit report lag telah dilakukan, dengan hasil yang menunjukkan beberapa faktorfaktor secara signifikan mempengaruhi audit report lag diantaranya; ukuran perusahaan, profitabilitas, ukuran kantor akuntan publik, auditor opinion, leverage, sovabiltas, jenis industri dan operasi laba/rugi. Penelitian ini bertujuan untuk menganalisis faktor-faktor yang mempengaruhi audit report lag di beberapa perusahaan di Indonesia. Penelitian ini menguji pengaruh ukuran perusahaan, profitabilitas, solvabilitas, umur perusahaan, ukuran kantor akuntan publik (KAP) dan komite audit terhadap audit report lag. Jumlah sampel penelitian terdiri dari 332 perusahaan manufaktur yang terdaftar di Bursa Efek Indonesia untuk periode 2009-2012. Analisis hipotesis penelitian menggunakan regresi linear berganda. Hasil dari analisis regresi berganda menunjukkan profitabilitas dan ukuran kantor akuntan publik secara signifikan mempengaruhi audit report lag. Sedangkan ukuran perusahaan, solvabiltas, umur perusahaan dan komite audit tidak memiliki pengaruh terhadap audit report lag.
\end{abstract}

Kata kunci: Audit report lag, ukuran perusahaan, profitabilitas, solvabilitas, umur perusahaan, ukuran kantor akuntan publik (KAP), komite audit.

DOI: 10.20885/jabis.vol17.iss1.art5 


\section{RESEARCH BACKGROUND}

Timeliness of financial statements is considered as one of the important aspects that the users of accounting information concern (Afify, 2009). When financial statement is not presented timely, it will lose the value of information, because it is not available when the users of financial statement require consideration in decision-making.

Financial statement must be audited first so that it will be more reliable and trusted for the users when they use it for decision-making. Financial statement audit aimed to give an opinion about the fairness and appropriateness of the financial statement based on applicable principles. Financial statement audit conducted to provide assurance over the reliability of financial statement.

Nowadays, public companies in Indonesia have big improvement. This development will affect an increasing demand of audit financial statement (Rachmawati, 2008). In order to protect shareholders' interests in the capital market, the regulatory authorities worldwide, including those in Indonesia have issued several rules concerning the timeframe for information submission. According to the Badan Pengawas Pasar Modal (BAPEPAM), i.e. The Indonesian Capital Market Supervisory Agency Rule of 2011 listed companies are required to submit the audited annual financial statement to BAPEPAM and Indonesian Stock Exchange (IDX) at the latest at the end of the third month after the date of the statement (BAPEPAM, 2011).

Timeliness of the company in publishing its financial statement to the public and BAPEPAM depends on the length of the auditor in completing their audit work. Apadore Kogilavani and Marjan Mohd Noor (2013) stated timeliness implies that the financial information should be presented at an interval of time, to explain the changes that may affect the user of information in making predictions and decision. Thus, it will trigger a negative effect on the company and in order to subdue the audit report lags, reliable and timely accounting information are really needed as a catalyst to create confidence among investors.

The time frame referred as the audit report lag (ARL) is the number of days between a company's financial year-end and the date of the auditor's report (Bamber E. L., and Schoderbek, 1993). Audit report lag, which is the number of days from fiscal 
year end to audit report date, or inordinate audit lag, jeopardizes the quality of financial reporting by not providing timely information to investor. The delay in the disclosure of the auditor's opinion on the true and fair view of the financial information prepared by management exacerbates the information asymmetry and increase uncertainty in investment decision (Naimi, Mohammad, Shafie Rohami and Wan Nordin Wan Hussin, 2010).

Considering the importance of the timeliness of financial reporting for the users of financial statements in decision-making, the researchers were motivated to examine some of the factors that affect audit report lag. This research uses the term of audit report lag to describe the length of audit completion, because the object is the date on audit report that has been signed, which means that the audit report was issued legally. Hence, the objective of this research is to examine the influence of company size, profitability, solvability, age of company, accounting firm size and audit committee on audit report lag.

\section{LITERATURE REVIEW AND HYPOTHESIS FORMULATION}

The process to provide accounting information to the public gives information value from the audited financial statements, which will be determined by audit report lag. According Knechel and Payne (2001) audit report lag is the time period between the end of fiscal year and the date of the audit report of the company.

The completion of an audit of a company would require a relatively long time and sometime it make the publication of financial statement delayed. Duration of the audit completion by auditor can be seen from the difference of time between the date of financial statement and the date of auditor's opinion issued. In Rachmawati (2008) referred it as the auditor's report lag, which is the range of time between the company's fiscal year-end date and the date listed on the report of auditor's opinion.

Several previous researches have conducted to examine the factors that affect audit report lag of the company. Lianto and Kusuma (2010) examining the influence of company size, profitability, solvability, age of company, and industrial sector on audit report lag. Sample of research are 28 consumer goods industry companies and 11 multifinance companies listed in Indonesian Stock Exchange, selected using purposive 
sampling method during 2004-2008. The result shows that partially profitability, solvability and age of company significantly affect audit report lag, while company size and industrial sector has not significant influence on audit report lag. Rachmawati (2008) proved that audit report lag influenced by accounting firm size. Accounting firm size has significant influence on audit report lag. Afify (2009) found the evidence that the existence of audit committee significantly reduces audit report lag of the company.

The importance of the timeliness of financial reporting recognized by various interested parties because it is not only affect the value and quality of the financial statements, but also brings a negative reaction from the market (Lianto et.al, 2010). Timeliness of companies in publishing their financial reporting to the public depends on the timeliness of auditor in completing its audit work (audit report lag). Many factors affect audit report lag, both in terms of company's internal and external terms.

\section{The influence of Company Size on Audit Report Lag}

Company size as one of the characteristics of the company is an important factor to be tested in various researches. Related to the timeliness of annual financial statements, company size is also a function of the faster completion of financial reporting. The size of the company is also influenced by operational complexity, variability and intensity of transactions the company, which would certainly affect the timeliness of presenting financial statements to the public. Owusu_Ansah and Leventis (2006) has been analyzed that large companies are prompt reporters. Company in a big scale is tend to be more faster in presenting audited financial statement compared with small company. Generally, large company monitored by investor, capital securities, and government, so there is tendency to reduce audit report lag (Lianto et.al, 2010). Rachmawati (2008) in the result of research has showed that there is significant relationship between company size and audit report lag. Kartika (2009) proved that company size significantly affect audit report lag. The larger the company size, the smaller the delay in the completion of financial statement. Conversely, Lianto et.al. (2010) stated that company size has no influence on audit report lag. Therefore the first hypothesis is:

$\mathrm{H}_{1}$ : There is a negative relationship between company size and audit report lag 


\section{The influence of Profitability to Audit Report Lag}

Financial performance information, especially the profitability necessary to assess potential changes in economic resources might be controlled in the future. Profitability is also used as an indicator of the success of the performance of company to generate profit. Company that has a higher level of profitability takes time in auditing financial statements more quickly due to the necessity to bring good news to the public immediately. They also argued about the auditor of the company that facing a loss has responses tend to be more careful in the process of auditing. If the company produces a higher level of profitability, the audit report lag will be shorter than firms with lower levels of profitability (Lianto et.al, 2010). Also it was shown profitability has influence on audit report lag. This result proved by Estrini and Laksito (2013) that profitability significantly affect audit report lag. However, it was stated that profitability has no influence on audit report lag. Based on these descriptions, the second hypothesis is:

$\mathrm{H}_{2}$ : There is a negative relationship between profitability and audit report lag

\section{The influence of Solvability to Audit Report Lag}

Solvability is a possibility and a long-term ability of the company to pay off long-term liabilities. According to Lianto et.al (2010) the company that has high amount of debt will lead to a relatively long audit process. The proportion of debt to total assets is high also may make the auditor needs to improve the carefulness and precision in auditing related to the going concern issue of the company. So, the higher the ratio of debt to total assets, the longer the time range required for the completion of the audit process of financial statements. Research by Lianto et.al (2010) found that there is influence of solvability on audit report lag. On the other hand, Rachmawati (2008) argued that there is no influence of solvability on audit report lag, Hence, the third hypothesis proposed:

$\mathrm{H}_{3}$ : There is a positive relationship between solvability and audit report lag 


\section{The influence of Age of Company to Audit Report Lag}

Companies with older age tend to be more skilled in collecting, processing and producing information when needed, because the company has gained considerable experience (Saleh, 2004). The company has had a lot of experience on a variety of issues related to information processing and how to overcome them. The company also has felt the changes that occur during operations, so companies tend to have flexibility in dealing with the changes that will occur. This makes the company capable of presenting more timely financial statements. According to Lianto et.al (2010) age of company negatively affect audit report lag. So, the older the age of company the faster the audit process. Amilia and Setiady (2006) argued that the greater the age of company, the faster the time completion of audit process, Lianto et.al (2010) stated that age of company will affect negatively on audit report lag. Accordingly, the fourth hypothesis is:

$\mathrm{H}_{4}$ : There is a negative relationship between age of company and audit report lag

\section{The influence of Accounting firm size to Audit Report Lag}

According to Estrini et.al (2013) accounting firm hired by the company to audit the financial statements will affect the public confidence in the credibility of financial statements produced by the company. In addition a large public accounting firm has accountants certainly more qualified and experienced than a small public accounting firm in order to work faster and on time. A Large audit firm is often referred to the big four. Company that uses the services of the big four firm tend to be more trustworthy when compared to companies who use the service of the non-big four firms (Juanita and Satwiko, 2012). Based on previous research it can be concluded that companies that use big four of audit firm services will tend to be more timely in submitting its financial statements because it has good quality audit. Rachmawati (2008) stated that there is significant influence of accounting firm size on audit report lag, then Estrini and Laksito (2013) has showed that accounting firm size significantly affect audit report lag, while Juanita et.al (2012) found there is no influence of accounting firm size on audit report lag. Therefore the fifth hypothesis as follow:

$\mathrm{H}_{5}$ : There is a negative relationship between accounting firm size and audit report lag 


\section{The influence of Audit Committee to Audit Report Lag}

The condition of company internally is influenced by audit committee. In accordance with the regulations of BAPEPAM rule number IX.I.5: Guidelines on establishment and working implementation of audit committee, attachment of the chairman decision, number: Kep-643/BL/2012 stated that every public company required to establish an audit committee with the audit committee structure of at least three persons who chaired an independent commissioner and two persons from outside companies that are independent toward the company. Audit committee play a vital role in ensuring strengthening communication between management and the external auditor, influences auditors' assessments of both control risk and audit risk, planned audit hours and the level of substantive testing, and good financial reporting; and hence reduce the ARL (Afify, 2009). Afify (2009) provide evidence that existence of an audit committee is significantly associated with audit report lag. Hence the last hypothesis proposed:

$\mathrm{H}_{6}$ : There is a negative relationship between the existence of audit committee and audit report lag.

\section{Figure 1: Research Model}

\section{Independent Variable}

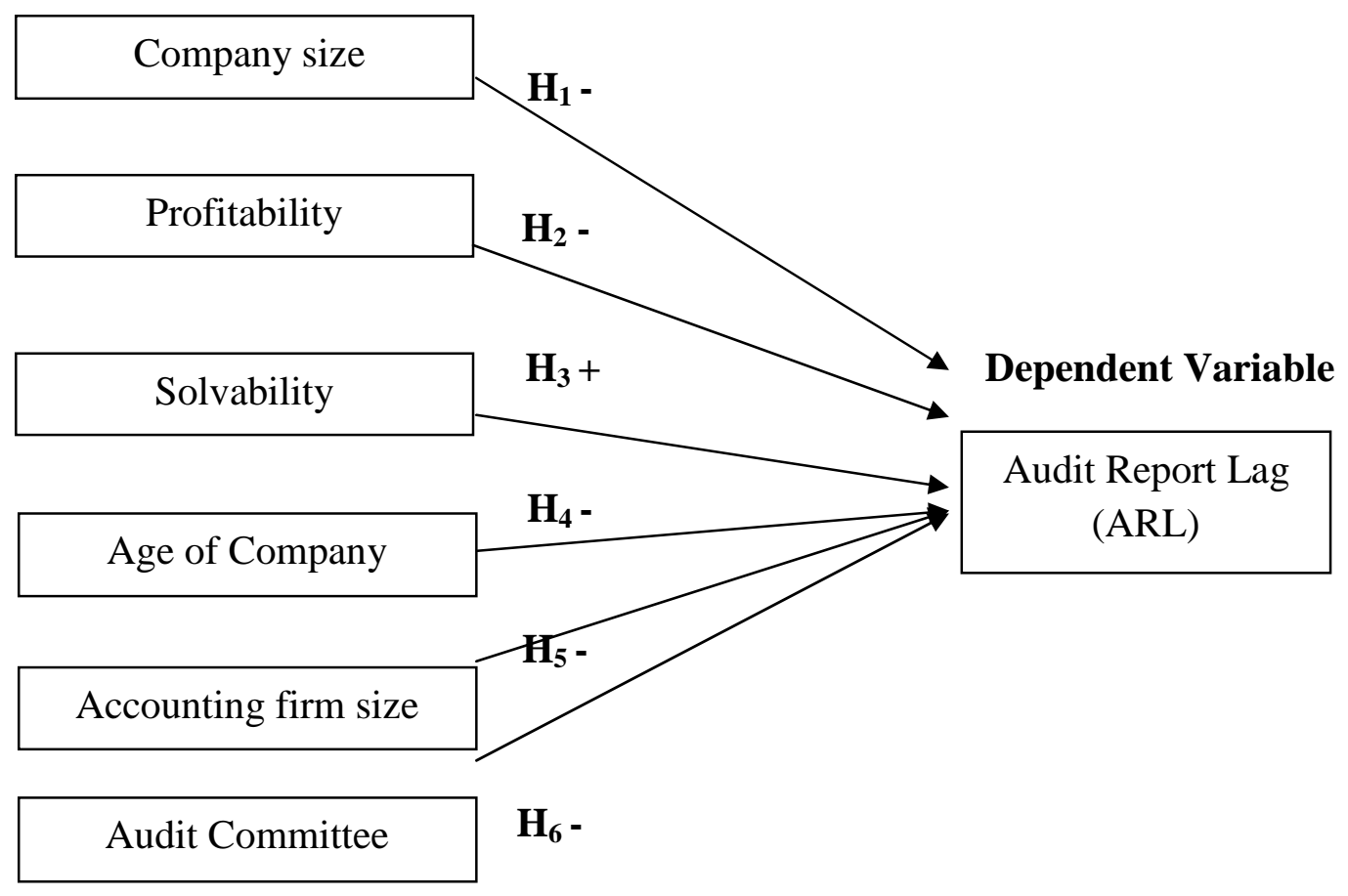




\section{RESEARCH METHOD}

\section{Population and Sample}

Population in this research is manufacturing companies listed at Indonesian Stock Exchange in 2009-2012. Sample in this research was selected using purposive sampling method, which is sampling technique with certain criteria. The samples are manufacturing companies listed in Indonesia Stock Exchange with the following criteria: 1) Manufacturing companies listed on Indonesian Stock Exchange respectively for the period 2009-2012 and the financial statement ended on December 31. 2) The company that has total of assets more than 500 billion rupiah. 3) The company has an organizational structure to indicate the audit committee. 4) The company does not use foreign currency. 5) The company publishes audit report issued by independent auditor. 6) The company publishes data required in this research. Based on these criteria, 83 companies selected as companies sample and the total of samples in the period of observation for four years is 332 samples.

\section{Table 1: Sample Selection}

\section{Criteria Amount}

Population of manufacturing company in period of 2009-2012 153

Company that has total asset less than 500 billion rupiah

Company that do not publish audit report.

Companies that do not have complete data for research

Delisting

Companies sample selection

Total of samples in the period of observation for 4 years

Source: Secondary data processed, 2014

\section{Research Variable}

Dependent variable in this research is audit report lag which is the number of days between financial statement at the year and the date of audit report. Audit report lag is measured by the total of day from the date of fiscal year end of the company until the audit report completed. 
Independent variables that will be examined are company size, profitability, solvability, age of company, accounting firm size and audit committee. Company size is measured by log of total assets, which is the total asset from both of current assets and noncurrent assets owned by the company. Profitability measured by return on asset (ROA) ratio, which is dividing net income to total of asset. Solvability is proxied by ratio of total debt to total assets that measured in total debt divided by total asset. Age of company is measured by the age of company since the company is listing in IDX until the year of research observation. Accounting firm size this research is based on the classification of the auditor who audited the company. This variable used dummy variable, if the auditor are from big four firm: Price Waterhouse Cooper, Ernst and Young, KPMG, and Delloite then it will be 1, otherwise it will be 0. Audit committee measured by dummy variable, where it will be 1 if the firm has an audit committee, 0 otherwise.

\section{Data Analysis Method}

This research uses multiple regression analysis to test the hypothesis. The model must meet the classical assumption of the linier regression, which consists of normality test, multicollinearity test, heteroscedasticity test, and autocorrelation test. SPSS software analysis will be used to carry out the analysis. The model of regression is formulated as follow:

\section{$A U D L A G=\beta o+\beta_{1} \mathrm{SIZE}+\beta_{2} \mathrm{ROA}+\beta_{3} \mathrm{SLV}+\beta_{4} \mathrm{AGE}+\beta_{5} \mathrm{BIG} 4+\beta_{6} \mathrm{AUDC}+\varepsilon$}

Where;

$\begin{array}{ll}\text { AUD_LAG } & =\text { Number of days from fiscal year end to the date of audit report. } \\ \text { SIZE } & =\text { Company size } \\ \text { ROA } & =\text { Profitability, proxies by return on asset } \\ \text { SLV } & =\text { Solvability, proxies by total debt to total asset } \\ \text { AGE } & =\text { Age of Company } \\ \text { BIG4 } & =\text { Accounting firm size } \\ \text { AUDC } & =\text { Audit Committee } \\ \varepsilon & =\text { Error }\end{array}$


Hypothesis test is conducted in this research using t-test and F-test with significance level $(\alpha)$ of 5 percent or 0.05 . t-test was used to test whether the independent variables are partial influence on the dependent variable Hypothesis formulations are:

$\mathrm{H}_{0}$ : p-value $>0.05$, it means there is no significant influence of independent variable on the dependent variable.

$\mathrm{H}_{\mathrm{a}}: \mathrm{p}$-value $<0.05$, it means there is a significant influence of independent variables on the dependent variable.

F test basically shows whether all the independent variables are included or free in the model have simultaneously influence on the dependent variable. Hypothesis formulations are:

$\mathrm{H}_{0}$ : p-value $>0.05$, it means there is no significant influence simultaneously of the independent variable on the dependent variable.

Ha: p-value $<0.05$, it means there is a significant influence simultaneously of the independent variable on the dependent variable.

\section{RESULTS AND DISCUSSION}

\section{Classical Assumption}

Classical assumption model is supposed to obtain more accurate results that are close or equal to the reality. This is a statistical requirement for multiple regression analysis. In this research, the researchers uses four tests with classical assumption; normality test, multicollinearity test, heteroscedasticity test and autocorrelation test.

\section{Normality Test}

Normality test in this research uses P-Plot Test. Testing for normality can be detected by looking at the spread of the data (dots) on the diagonal axis of the normal graph. The result of P-Plot test can be seen as follows 


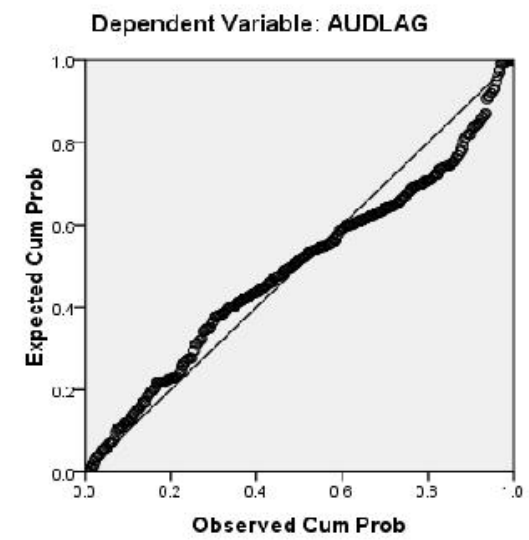

Source: Secondary data processed, 2014

Based on normality graph present in the figure 2 (Normal P-Plot of Regression Standardized Residual), it can be seen that dots spread around the diagonal line, and its distribution follows the direction of the diagonal line, indicating that the regression model is feasible to used because it meet the normality assumption.

\section{Multicollinearity Test}

Multicollinearity occurs when there is a linear relationship between the independent variables included in the regression model. Testing can be performed by analyzing the calculation of the value of tolerance and the Variance Inflating Factor (VIF). If the VIF value $>10$ and tolerance values $<10 \%$, then the regression model multicollinearity occurs, however, if the VIF value $<10$ and tolerance values $>10 \%$, then there is no multicollinearity. The result of multicollinearity can be seen as follows

Table 2: The Result of Multicollinearity Test

\begin{tabular}{|c|c|c|}
\hline \multirow{2}{*}{ Variable } & \multicolumn{2}{|c|}{ Collinearity Statistics } \\
\cline { 2 - 3 } & Tolerance & Tolerance \\
\hline SIZE & .768 & 1.302 \\
\hline ROA & .860 & 1.163 \\
\hline SLV & .915 & 1.093 \\
\hline
\end{tabular}




\begin{tabular}{|c|c|c|}
\hline AGE & .929 & 1.076 \\
\hline BIG4 & .742 & 1.348 \\
\hline AUDC & .988 & 1.012 \\
\hline
\end{tabular}

Source: Secondary data processed, 2014

Table 2 above shows that there is no multicollinearity in all of independent variables that used in the regression model. It can be shown from tolerance value $>0.1$ for variable of SIZE, ROA, SLV, AGE, BIG4, AUDC, and also the value of VIF in all of independent variable $<10$.

\section{Heteroscedasticity Test}

Heteroscedasticity test in this research is based on scatter plot. This test can be done by looking at the image plot between the predicted value of the independent variable (ZPRED) with residual (SRESID). If there is no clear pattern in the graphs and the data are randomly distributed as well as the points spread above and below the number 0 on the $\mathrm{Y}$ axis, then there is no heteroscedasticity. Based on test with SPSS, scatter plot graph obtained as follows:

Figure 3: The Result of Heteroscedasticity Test

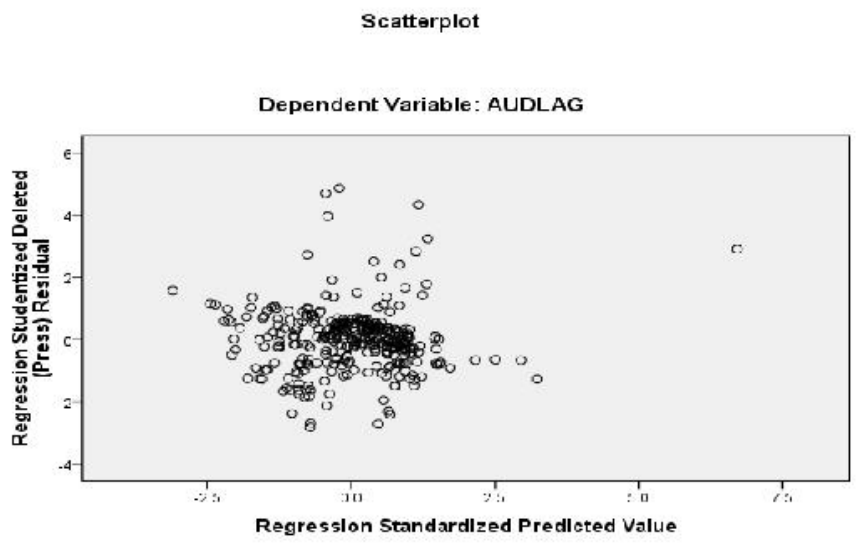

Source: Secondary data processed, 2014

Based on the scatter plot graph, it can be look the point spread at random, do not form a specific clear pattern or regular, and the point spread above and below the 0 on the y-axis. Thereby it can be concluded that no symptoms of heteroscedasticity in 
regression models, so the regression model feasible used to predict the factors that affect the audit report lag.

\section{Autocorrelation Test}

Autocorrelation test is used to test whether there is a correlation in regression model between the disturbance mistakes in the $\mathrm{t}$ period and mistakes in $\mathrm{t}-1$ period or not. This research is used Durbin-Watson test to identified whether there is autocorrelation or not in the regression model. The result of Durbin-Watson test can be shown in this table 3 below:

Table 3: The result of autocorrelation test using Durbin-Watson test

\begin{tabular}{llllll}
\hline Model & dL & dU & 4-dU & 4-dL & DW \\
Audit Report Lag & 1.707 & 1.831 & 2.169 & 2.293 & 1.893 \\
\hline (n=332, k=6, significant level ( $\boldsymbol{\alpha})$ of 5\%) \\
Source: Secondary data processed, 2014
\end{tabular}

Based on table 3 above, the value of DW is located between the upper limit and upper bound $(\mathrm{du})$ and $(4-\mathrm{du})$ which are $1.831<1.893<2.169$ therefore it can be conclude that there is no autocorrelation in the regression model.

\section{Multiple Regression Analysis}

Table 4: The Result of Multiple Regression Analysis

\begin{tabular}{|c|c|c|c|c|c|}
\hline & $\begin{array}{l}\text { Unstanc } \\
\text { Coeff }\end{array}$ & $\begin{array}{l}\text { ardized } \\
\text { ients }\end{array}$ & $\begin{array}{c}\text { Standardized } \\
\text { Coefficients }\end{array}$ & & \\
\hline Model & B & Std. Error & Beta & $\mathbf{t}$ & Sig. \\
\hline (Constant) & 99.281 & 22.210 & & 4.470 & .000 \\
\hline SIZE & -.764 & .798 & -.057 & -.957 & .339 \\
\hline ROA & -.232 & .074 & -.176 & -3.119 & .002 \\
\hline SLV & 4.768 & 2.501 & .104 & 1.906 & .057 \\
\hline AGE & -.068 & .160 & -.023 & -.427 & .670 \\
\hline BIG4 & -4.082 & 1.970 & -.126 & -2.072 & .039 \\
\hline AUDC & 3.140 & 1.933 & .085 & 1.624 & .105 \\
\hline
\end{tabular}

Source: Secondary data processed, 2014 
Table II shows the results of multiple regression analysis, the regression equation based on the results can be formulated as follows:

$$
\begin{aligned}
\text { AUDLAG }= & 99.281-0,764(\text { SIZE })-0.232(\text { ROA })+4.768(\text { SLV })-0.068(\text { AGE })- \\
& 4.082(\text { BIG4 })+3.140(\text { AUDC })+\mathrm{e}
\end{aligned}
$$

$H_{1}$ : There is a negative relationship between company size and audit report lag.

The findings support this hypothesis but it does not significantly relate to the audit report lag. The result of multiple regression analysis shows that company size has no significant influence on audit report lag. The coefficient of SIZE is negative but statistically not significant $(p=0.339)$. The greater or the smaller of the total assets owned by the company regarding to the size of company does not affect audit report lag. This result is consistent with the research conducted by Lianto et.el (2010). All companies continually monitored by investors, regulators and other parties so that each company is required to immediately complete the audit of financial statements. However, this result is not in line with research conducted by Almilia et.al (2006) and Kartika (2009) that shows the significant influence between company size and audit report lag.

\section{$\mathrm{H}_{2}$ : There is a negative relationship between profitability and audit report lag}

The findings support the above hypothesis. The result of multiple regression analysis shows that profitability has significant influence on audit report lag. The coefficient of ROA is negative and statistically significant $(p=0.002)$. The higher the profitability levels of a company, the smaller the audit report lag. Company that has a higher level of profitability is more quickly in auditing financial statements due to the necessity to bring good news to the public immediately. This result is consistent with Lianto et.al (2010), Estrini et.al (2013) but inconsistent with the research result by Juanita and Satwiko (2012).

\section{$\mathrm{H}_{3}:$ There is a positive relationship between solvability and audit report lag}

The result of multiple regression analysis shows that solvability has no significant influence on audit report lag. The coefficient of SLV is positive but statistically not significant $(p=0.057)$. The greater or the smaller the solvability ratio 
does not affect audit report lag of company. This result is consistent with Rachmawati (2008). However, this result is not in line with Lianto et.al (2010) that show the significant influence of solvability toward audit report lag. The result of their research stated the company that has high amount of debt will lead to a relatively long of audit process. The proportion of debt to total assets is high also may make the auditor needs to improve the carefulness and precision in auditing related to the going concern issue of the company.

\section{$H_{4}:$ There is a negative relationship between age of company and audit report lag.}

The result of multiple regression analysis shows that age of company has no significant influence on audit report lag. The coefficient of AGE is negative but statistically not significant $(p=0.670)$. Based on the research result, the greater or the smaller the age of company since the company listing in IDX does not affect audit report lag of company. This result is not in line with Almalia et.al (2006), and Lianto et.al (2010).

\section{$H_{5}:$ There is a negative relationship between accounting firm size and audit report lag.}

The result of multiple regression analysis shows that accounting firm size has significant influence on audit report lag. The coefficient of BIG4 is negative and statistically significant $(p=0.039)$. Companies audited by big 4 firm tend to report their financial statements more quickly because big 4 firm is firm that has a good reputation, so that the firm has a good resource. The existence of a good resource in the firm makes professionalism of auditors better supported with good equipment. Thus, the completion of the audit financial statement will be faster. This result is consistent with Rachmawati (2008) and Estrini et.al (2013). Moreover, this research obtained different result with the research by Juanita et.al (2012) which found that there is no influence between accounting firm size and audit report lag. 


\section{$H_{6}:$ There is a negative relationship between audit committee and audit report lag.}

The result of multiple regression analysis and hypothesis 6 shows that audit committee has no significant influence on audit report lag. The coefficient of AUDC is positive and statistically not significant $(p=0.105)$. Company that show the existence or non existence of audit committee does not affect audit report lag of company. The result in this research is not consistent with Afify (2009) who prove that the existence of audit committee can reduce audit report lag, because this research is conducted in Indonesia and the previous research was conducted in Egypt where the condition of the companies are different. This research is conducted from the year 2009 until 2012, at that period not all the companies have audit committee. Therefore there is insignificancy in the result. This research is only concerned on the existence of audit committee in certain companies, while the previous research by Ika and Ghazali (2011) measured the effectiveness of audit committee on the timeliness of financial reporting both by the existence of audit committee and by other components of audit committee, such as audit committee size and audit committee expertise investigated, so that the audit committee effectiveness is a significant factor to Ika et.al (2011), in order to ensure timely submission of audited financial statements.

\section{CONCLUSSION}

This research is aimed to examine the factor that influence audit report lag in manufacturing companies listed on Indonesia Stock Exchange (IDX). The results indicate that profitability and accounting firm size significantly affected audit report lag. Profitability has negative significant influence on audit report lag. This means company that has higher level of profitability may reduce audit report lag than the company that has lower level of profitability. Accounting firm size has negative significant influence on audit report lag. This means the company audited by Big 4 of accounting firm may reduce audit report lag than the company that audited by non Big 4 of accounting firm. However, the result also shows that company size, solvability, age of company, and audit committee does not influence audit report lag.

Limitations of this research are: 1) Based on the result of adjusted $\mathrm{R}^{2}$, it shows the limitation of variable used in this research that can explained audit report lag as the 
dependent variable. This research is only considered using some of independent variable, which is profitability, solvability, age of company, accounting firm size, and audit committee. In this research there are some of data that have not complete information or the data required is not available, thus it makes reduce the sample. This research consists of 83 companies from 153 total of manufacturing companies listed in Indonesian Stock Exchange in year of 2009 until 2012. Thus, this research only uses limited sample to be researched.

On the basis of the result research and its limitation, it is recommended that for further researcher could add other variables that may affect audit report lag such as auditor opinion, leverage, type of industry, loss or profit and ownership structure. Moreover, further researcher could concentrate in internal factor of company such as corporate governance mechanism and its influence on audit report lag. Based on these limitations, the researcher suggests for further research use the research object of non manufacturing companies, such as the financial sector or the research of entire go public company and the number of samples can be added in order to obtain better results.

\section{REFERENCES}

Afify, H.A.E.(2009). Determinants of audit report lag: Does implementing corporate governance have any impact? Empirical evidence from Egypt. Journal of Applied Accounting Research, 10(1), 56-86.

Almilia, Luciana Spica dan Setiady, Lucas.(2006). Faktor-Faktor yang Mempengaruhi Penyelesaian dan Penyajian Laporan Keuangan pada Perusahaan yang Terdaftar di BEJ. Seminar Nasional Good Corporate Governance. Universitas Trisakti Jakarta, page 1-28.

Apadore, K., and Noor, M.M., (2013). Determinants of Audit Eport Lag and Corporate Governance in Malaysia. International Journal of Business and Management ,151-163 
BAPEPAM (2011), Decree No. KEP-346/BL/2011 Concerning Obligation to Submit Annual Report for Issuer and Public Companies, BAPEPAM. website: http://www.bapepam.go.id. Retrieved on 22 October 2013

Bamber, E. L., and Schoderbek. (1993). Audit Structure and Other Determinants of Audit Report Lag: An Empirical Analysis. Journal of Practice and Theory, Vol.12, No.1,pp. 1-23.

Estrini, D. H., and Laksito, Heri. (2013). Analisis Faktor-faktor yang mempengaruhi Audit Delay. Diponegoro Journal of Accounting Volume 2, Nomor 2, Tahun 2013, Halaman 1 http://ejournal-s1.undip.ac.id/index.php/accounting ISSN (Online): 2337-3806

Ika, Siti Rochmah and Ghazali Nazli A, M. (2011). Audit Committee Effectiveness and Timliness of Reporting: Indonesian Evidence. Managerial Auditing Journal Vol. 27 No. 4, 2012 pp. 403-424

Juanita, Greta and Satwiko, Rutji. (2012). Pengaruh Ukuran Kantor Akuntan Publik, Kepemilikan, Laba Rugi, Povitabilitas dan Solvabilitas terhadap Audit Report Lag. Jurnal Bisnis dan Akuntansi Vol. 14, No. 1, April 2012, Hlm. 31 - 40

Kartika, Andi. (2009). Faktor-Faktor yang Mempengaruhi Audit Delay di Indonesia (Studi Empiris pada Perusahaan-Perusahaan LQ 45 yang Terdaftar Di Bursa Efek Jakarta). Jurnal Bisnis dan Ekonomi (JBE), Maret 2009, Hal. 1 - 17 Vol. 16, No.1 ISSN: 1412-3126

Knechel, W. R. and J. L. Payne. (2001). Additional evidence on audit report lag. Auditing: A journal of Practice and theory, 137-146. 
Lianto, Novice and Kusuma, Budi Hartono. (2010). Faktor-faktor yang Berpengaruh Terhadap Audit Report Lag, Jurnal Bisnis dan Akuntansi,Vol.12,No.2.Agustus 2010, Hlm.97-106

Naimi, Mohammad, Shafie Rohami and Wan Nordin Wan Hussin. (2010). Corporate Governance and Audit Report Lag in Malaysia. Asian Academy of Management journal of Accounting and Finance, Vol 6, 57-84.

Owusu-Ansah, S. and Leventis, S. (2006), Timeliness of corporate annual financial reporting in Greece, European Accounting Review, Vol. 15, pp. 273-87.

Rachmawati, Sistya. (2008). Pengaruh Faktor Internal dan Eksternal Perusahaan Terhadap Audit Delay dan Timeliness. Jurnal Akuntansi dan Keuangan, 10(1): $1-10$.

Saleh, R. (2004). Studi Empiris Ketepatan Waktu Pelaporan Keuangan Perusahaan Manufaktur di Bursa Efek Jakarta. Simposium Nasional Akuntansi VII (Desember),897-910. 